\title{
Correction to: Analyzing territory for the sustainable development of solar photovoltaic power using GIS databases
}

\author{
Inmaculada Guaita-Pradas • \\ Inmaculada Marques-Perez • Aurea Gallego • \\ Baldomero Segura
}

Published online: 3 April 2020

(C) Springer Nature Switzerland AG 2020

Correction to: Environ Monit Assess (2019) 191: 764 https://doi.org/10.1007/s10661-019-7871-8

The original version of this article unfortunately contained an error.

The authors acknowledge the support received from the Generalitat Valenciana through the research project "Sustainability of the Food Value Chain: From Production to Responsible Consumption" (Ref. AICO/2017/ 066).

Publisher's note Springer Nature remains neutral with regard to jurisdictional claims in published maps and institutional affiliations.

The online version of the original article can be found at https://doi.org/10.1007/s10661-019-7871-8

I. Guaita-Pradas · I. Marques-Perez $(\bowtie) \cdot$ B. Segura Departamento de Economía y Ciencias Sociales, Universitat Politècnica de València, Valencia, Spain

e-mail: imarques@esp.upv.es

A. Gallego

Departamento de Ingeniería Cartografica, Geodesia y Fotogrametria, Universitat Politècnica de València, Valencia, Spain 